\title{
Influence of Root-Inducing Substances and Time Intervals on the Rooting of Acerola Cuttings
}

\author{
Raúl Abrams and George C. Jackson ${ }^{1}$
}

INTRODUCTION

Since the report of the high ascorbic acid content of the juice of its fruit $(1)^{2}$, the acerola (Malpighia punicifolia L.), has become a potential economic crop for Puerto Rico. Beginning with fieldwork at the Agricultural Experiment Station, plantings of acerola have been expanding (2) and, at present, a processing plant is operating on the Island and the juice is exported to world markets.

The propagation of hardwood cuttings of acerola is still comparatively recent and no information is available on the root development and propagation by the use of root-inducing substances on cuttings. Since acerola has great economic potentialities for Puerto Rico it was felt that information was needed concerning its propagation by using root-inducing substances. The work performed covers not only the development of roots by the use of hormones, but also the time interval required for maximum root development.

\section{MATERIALS AND METHODS}

The study on the rooting of acerola cuttings was started on May 17, 1957 , and completed on July 16, 1957. Ten-inch-long hardwood terminal cuttings were taken from healthy 6-year-old acerola trees of clone B. 15 . The cuttings were trimmed to 8-inch lengths and the leaf areas were kept at a maximum for, under these conditions, better rooting responses have been reported on other plants (3). The cuttings were treated with commercial preparations of indolebutyric and naphthaleneacetic acids which have been reported effective in the rooting of cuttings (4).

The treatment consisted of moistening the basal ends of the cuttings and immersing them in the appropriate hormone powder to a depth of one-half inch. The excess powder was removed by tapping the cuttings gently.

The experimental design was a split-plot one in which the two hormone treatments and the control were studied in the whole plots. A subplot consisted of 100 cuttings set 1 inch deep in holes previously made in fumi-

${ }^{1}$ Assistant Agronomist and Research Assistant in Horticulture, respectively, Agricultural Experiment Station, University of Puerto Rico, Río Piedras, P.R. The authors wish to thank I. S. Bangdiwala, Associate Statistician in charge of the Statistics Section, for his collaboration in preparing the statistical tables of the data.

2 Italic numbers in parentheses refer to Literature Cited, p. 158. 
gated sand beds. The spacing between cuttings was 2 inches both ways. The cuttings were dug from the sand beds at 6-, 8-, and 10-week intervals and rooting percentages and root counts were recorded for each treatment. All treatments were replicated four times.

The cuttings received 80-percent natural light and, through the use of electrically controlled humidifying equipment, they also received 5 seconds of overhead mist spray per minute during daylight hours.

\section{EXPERIMENTAL RESULTS AND DISCUSSION}

EFFECT OF ROOT-INDUCING SUBSTANCES ON THE ROOTING OF CUTTINGS

Data on the mean rooting percentages of acerola cuttings treated with root-inducing substances and left in the sand beds during 6,8 , and 10 weeks are presented in table 1 and figure 1.

The standard errors and least differences for significance between means are shown in the following tabulation:

\section{Ilems}

5 percent 1 percent

\section{Hormone treatments}

Difference between highest and lowest means

Difference between 2 adjacents

12.4

18.1

Standard error 2.86 with 6 d.f.

Time periods

Highest and lowest

Difference between 2 adjacents

Standard error 2.05 with 18 d.f.

$9.9 \quad 15.0$

Between time intervals for same hormone treatment

Highest and lowest

12.8

Difference between 2 adjacents

10.5

14.4

Standard error 3.54 with 18 d.f.

Between any 2 hormones for same time interval

Highest and lowest

16.2

22.4

Difference between 2 adjacents

Standard error 4.07

Table 1 shows that, when the cuttings were treated with indolebutyric acid, the response in the number of cuttings that rooted was significant at the 5-percent level. The response of acerola cuttings to the root-inducing substances is presented in a graphic form in figure 1, the uppermost line represents indolebutyric acid and the lowest one the control, indicating a definite response of the cuttings to the use of indolebutyric acid. However, the average difference in mean rooting percentage was not significant between the two hormone treatments. 

JOURNAL OF AGRICULTURE OF UNIVERSITY OF PUERTO RICO

TABLE 1.-Mean rooling percentages of acerola cuttings of $B .15$ clone treated with root-inducing substances and left in the sand beds for 6,8 , and 10 weeks

\begin{tabular}{l|c|c|c|c}
\hline \multirow{2}{*}{ Treatments } & \multicolumn{2}{|c|}{ Results after number of weeks indicated } & \multirow{2}{*}{ Mean } \\
\cline { 2 - 3 } & 6 & 8 & 10 & \\
\hline Indolebutyric acid & 39.3 & 68.5 & 70.0 & 59.3 \\
Naphthaleneacetic acid & 39.3 & 62.0 & 65.5 & 55.6 \\
Control & 29.3 & 55.8 & 54.8 & 46.6 \\
\cline { 2 - 4 } Mean & 36.0 & 62.1 & 63.4 & 53.8 \\
\hline
\end{tabular}

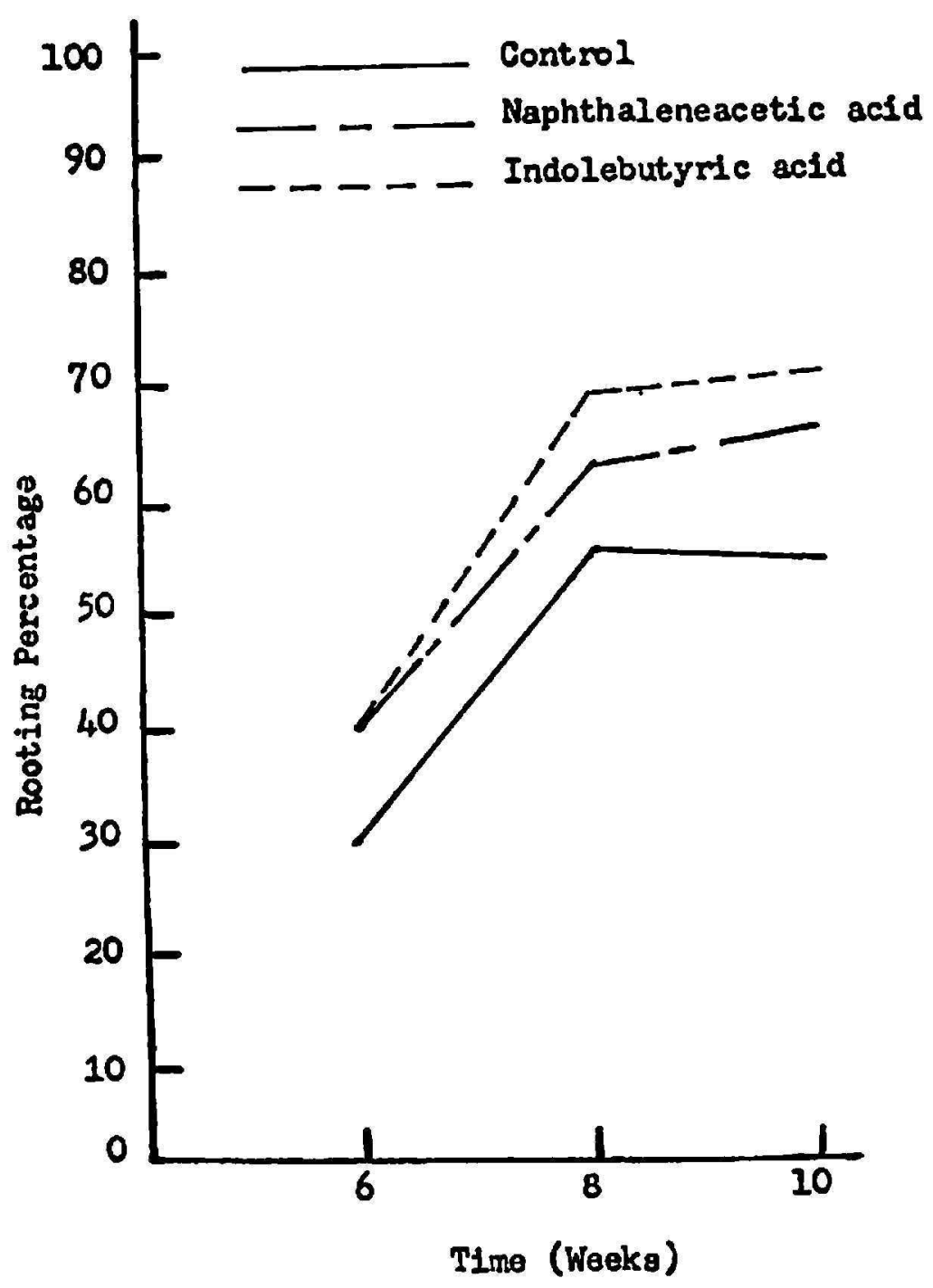

Fig. 1.-Average rooting percentage of acerola cuttings treated with root-inducing substances and left in the sand beds for 6,8 , and 10 weeks. 


\section{EFFECT OF DIFFERENT TIME INTERVALS}

The results of different time intervals are also presented in table 1 and figure 1. Leaving the cuttings in the sand beds for different time intervals definitely influenced the rooting percentages of the cuttings. The number of cuttings that rooted after 8 and 10 weeks in the sand beds showed significant differences at the 1-percent level over the 6-week period. However, there was no significant difference between the 8- and 10-week intervals, suggesting that of the three intervals studied, the 8-week one is the most appropriate to keep the cuttings in the sand beds.

This result is of importance because a reduction of 2 weeks in the time that the cuttings are to remain in the sand beds represents a more rapid propagation of the acerola and, at the same time, a larger number of cuttings can be propagated during a particular period of time. The mean rooting percentages for the 6-, 8-, and 10-week intervals were $36,62.1$, and 63.4 , respectively. This is represented graphically in figure 1, the two uppermost lines representing indolebutyric and naphthaleneacetic acid, respectively.

Table 1 also indicates that, for any combination of time and hormone treatment, the percentage of cuttings that rooted was significant at the 1-percent level when they were left in the sand beds for 8 and 10 weeks as compared to the 6-week time interval. The cuttings treated with indolebutyric acid had rooting percentages 6.5 percent higher after 8 weeks and 4.5 percent higher after 10 weeks than those treated with naphthaleneacetic acid.

According to the comparisons in table 1, there were significant differences in the rooting percentages when the cuttings were treated with hormones at a given time interval. However, these data do not suggest that treating the cuttings with hormones will not cause an increase in the number of cuttings that root, because the contrary is definitely shown in table 1 and figure 1.

\section{AVERAGE NUMBER OF ROOTS PER CUTTING}

The results on the average number of roots per cutting are presented in table 2 and figure 2. Treating the acerola cuttings with root-inducing substances definitely increased the number of roots per cutting. The response in the number of roots per cutting when treated with indolebutyric acid was significant at the 1-percent level over naphthaleneacetic acid and the control.

Leaving the cuttings in the sand beds for 8 weeks also caused an increase in the number of roots produced, as indicated in table 2. These data are very similar to those obtained on the rooting percentages of the cuttings. However, when indolebutyric acid was used, leaving the cuttings in the 
TABLE 2.-Mean number of roots per cutting of acerola clone B. 15 when treated with root-inducing substances and left in the sand beds for 6,8 , and 10 weeks

\begin{tabular}{l|c|c|c|c}
\hline \multirow{2}{*}{ Treatments } & \multicolumn{2}{|c|}{ Results after number of wceks indicated } & \multirow{2}{*}{ Mean } \\
\cline { 2 - 3 } & 6 & 8 & 10 & \\
\hline Indolebutyric acid & 3.9 & 4.4 & 4.4 & 4.2 \\
Naphthaleneacetic acid & 3.1 & 3.3 & 3.9 & 3.4 \\
Control & 1.9 & 2.5 & 2.6 & 2.3 \\
\cline { 2 - 3 } Mean & 3.0 & 3.4 & 3.6 & 3.3 \\
\hline
\end{tabular}

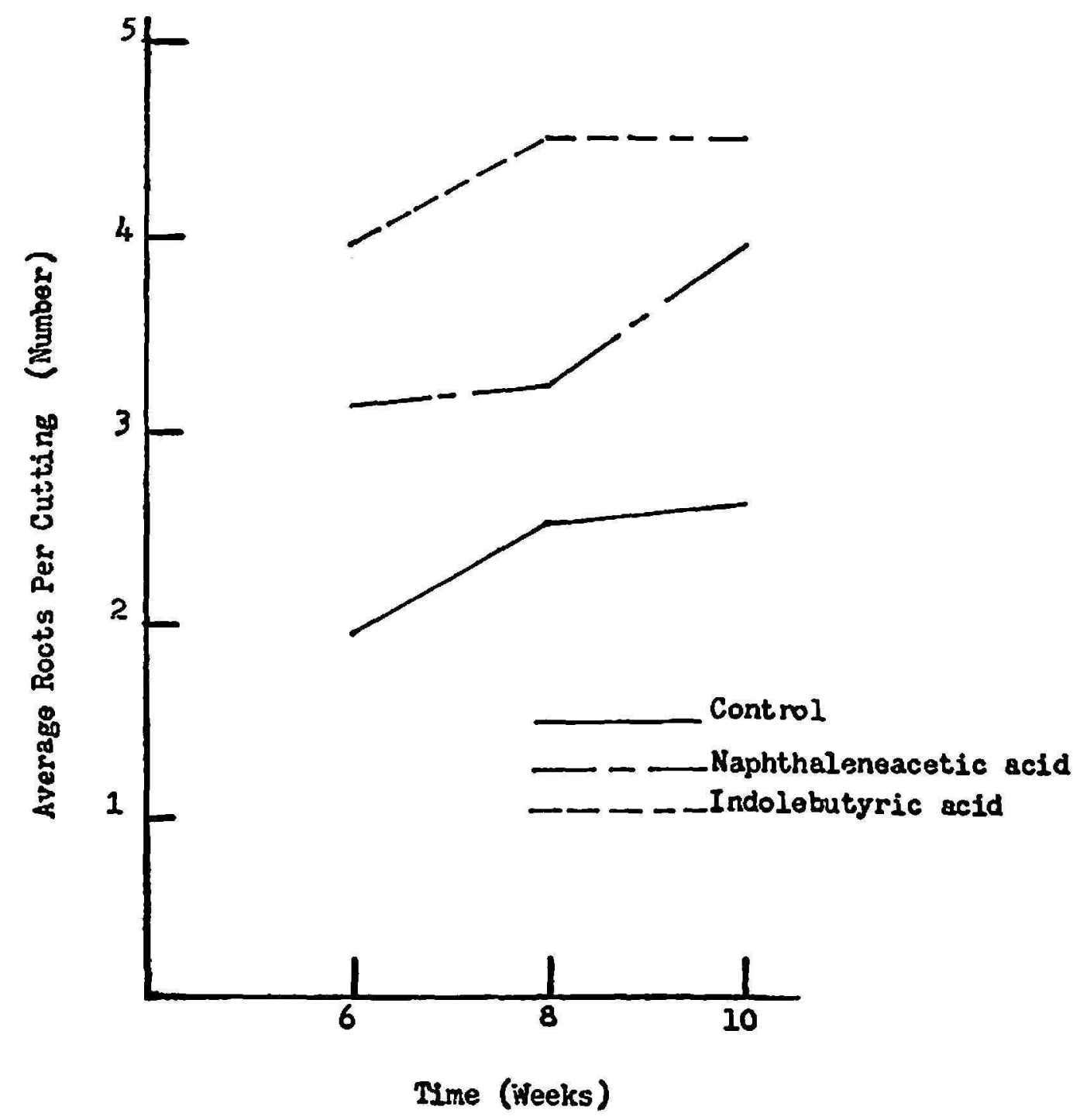

FIG. 2.-Average number of roots per cutting of acerola clone B. 15 when treated with root-inducing substances and left in the sand beds for 6,8 , and 10 weeks. 
sand beds from 8 to 10 weeks did not increase the number of roots, while a slight increase was observed with naphthaleneacetic acid and the control. There were highly significant differences in the number of roots per cutting when these were treated with indolebutyric acid and left in the sand beds for 8 weeks as compared to naphthaleneacetic acid and the control, according to table 2. Figure 2 gives a graphic presentation of these data.

The standard errors and least differences for significance between means are shown in the following tabulation:

Items

5 percent 1 percent

Hormone treatments

Difference between highest and lowest

Difference between 2 adjacents

Standard error 0.12 with 6 d.f.

Time periods

Highest and lowest

Difference between 2 adjacents

Standard error 0.14 with 18 d.f.

Between time intervals for same hormone treatment

Highest and lowest

Difference between 2 adjacents

Standard error 0.24 with 18 d.f.

0.5

Between any 2 hormones for same time interval

Highest and lowest

Difference between 2 adjacents

Standard error 0.23
.4

.5

.4

.7

$.7 \quad 1.0$

0.8

.6

.6

$.9 \quad 1.2$

$.7 \quad 1.0$

These results suggest that treating the cuttings with indolebutyric acid will result in: 1, A higher percentage of rooted acerola cuttings; and 2, a better production of roots per cutting, which at the same time increases the probabilities of survival of these cuttings when transplanted to the cans or the field.

\section{SUMMARY}

Because of the high ascorbic acid content of the pulp of its fruit, the acerola (Malpighia punicifolia L.) has good potentialities as an economic crop for Puerto Rico. The Agricultural Experiment Station therefore, has selected clones of a high ascorbic acid content of which B. 15 is one of the best. The best and most rapid type of true-to-type propagation for the selected clones is by means of cuttings.

In this experiment cuttings of acerola clone B. 15 were treated with 
indolebutyric and naphthaleneacetic acid and left in the sand beds for 6 , 8 , and 10 weeks. The major results were:

1. Indolebutyric acid significantly increased the number of cuttings that rooted.

2. Leaving the cuttings in the sand beds for 8 weeks proved this to be the optimum time interval for the rooting of the cuttings.

3. The use of the plant hormones significantly increased the number of roots per cutting.

\section{RESUMEN}

Por su alto contenido de ácido ascórbico, la acerola (Malpighia punicifolia L.) es una cosecha de gran potencialidad económica para Puerto Rico.

La Estación Experimental Agrícola de la Universidad de Puerto Rico ha venido seleccionando los tipos de este arbusto que producen frutas con el mayor contenido de ácido ascórbico. El método más rápido y eficiente para propagar estos tipos ha sido por medio de esquejes.

En el experimento que se ha informado aquí, se trataron los esquejes de acerola de la selección B. 15 con los ácidos indolbutírico y naftalinacético en polvo y luego se colocaron en propagadores de arena por períodos de 6 , 8, y 10 semanas.

Los resultados fueron los siguientes:

1. El tratamiento de los esquejes con ácido indolbutírico aumentó significativamente el número de esquejes que arraigaron.

2. El dejar los esquejes en los propagadores de arena por un período de 8 semanas resultó ser el tiempo óptimo para que éstos arraigaran.

3. El uso de hormonas aumentó significativamente el número de raíces de los esquejes tratados.

\section{LITERATURE CITED}

1. Asenjo, C. F., and Freire de Guzmán, F., The high ascorbic acid content of the West Indian Cherry, Sci. 103 219, 1946.

2. Aróstegui, F., Asenjo, C. F., Muñiz, A. I., and Alemañy, L., Observations and data on a promising selection of the West Indian Cherry, Malpighia punicifolia L., J. Agri. Univ. P. R. 39 (2) 1-51, 1955.

3. Zimmerman, P. W., Responses of plants to hormonelike substances, Ohio J. Sci., 37 333-48, 1937.

4. Zimmerman, P. W., and Wilcoxon, F., Several chemical growth substances which cause initiation of roots and other responses in plants, Contribution from Boyce Thompson Institute, 7 209-29, 1935. 